\title{
Santonian dinocyst assemblages of the Santa Marta Formation, Antarctic Peninsula: Inferences for paleoenvironments and paleoecology
}

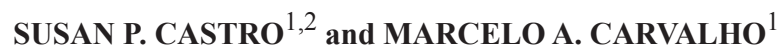 \\ ${ }^{1}$ Laboratório de Paleoecologia Vegetal, Departamento de Geologia e \\ Paleontologia, Museu Nacional, Universidade Federal do Rio de Janeiro, \\ Quinta da Boa Vista, s/n, São Cristóvão, 22040-040 Rio de Janeiro, RJ, Brasil \\ ${ }^{2}$ Programa de Pós-Graduação do Instituto de Geociências, \\ Universidade Federal do Rio de Janeiro, Cidade Universitária, s/n, \\ Ilha do Fundão, 21949-900 Rio de Janeiro, RJ, Brasil
}

Manuscript received on December 3, 2014; accepted for publication on January 26, 2015

\begin{abstract}
To better understand the paleoenvironments of the lower-middle Santonian, dinocyst data were obtained from the Santa Marta Formation, Larsen Basin, James Ross Island, Antarctic Peninsula. This study provides the first available quantitative dinocyst data for the Santa Marta Formation, which should more clearly reflect detailed changes in paleoenvironments, as recorded by fluctuations in diversity and abundance. To record the Santonian dinocyst assemblages from the Larsen Basin, 30 samples from an outcrop of the Lachman Crags Member (LC section) were analyzed. These assemblages are dominated by peridiniacean dinocysts typical of the Isabelidinium flora. A lower-middle Santonian age was determined after the recognition of Odontochitina porifera and Isabelidinium cretaceum zones. Cluster analysis based on quantitative data, yielded five dinocyst assemblages: Manumiella, Heterosphaeridium, Chlamydophorella, Isabelidinium and Odontochitina. Two Santonian blooms, Isabelidinium and Odontochitina, recognized in other regions were also recorded in the studied section. The stratigraphic distribution shows an alternation between the assemblages, distinguishing in the section six intervals. The high abundance of the Manumiella assemblage at the uppermost interval of the section represents the shallower setting, whereas the high abundance of Odontochitina at the middle part of the section represents the deepest setting.
\end{abstract}

Key words: Santonian dinocysts, Antarctica, Cretaceous, Santa Marta Formation, dinocyst blooms.

\section{INTRODUCTION}

The Larsen Basin contains one of the most extensive marine Cretaceous successions (Albian-Campanian) in the Southern Hemisphere (Francis et al. 2006). Dinocyst assemblages from the Santa Marta Formation (Santonian-Campanian) show significant differences in

Correspondence to: Susan Paiva de Castro

E-mail: susanpcastro@yahoo.com.br abundance and diversity in the succession. They show a distinct paleoenvironmental distribution pattern for the Santonian interval. This interval is characterized by Isabelidinium flora (Dettman and Thomson 1987), typical of near-shore conditions. However, the dinocyst assemblages used for paleoenvironmental interpretations differentiate between a more proximal and deeper setting in this section. 
In this study, we used cluster analysis to determine assemblages for the lower-middle Santonian section of the Santa Marta Formation. We also used ecological indices (diversity, equitability and dominance) to obtain a more detailed reconstruction of the paleoecology and depositional environments. The following issues are addressed in this study: 1) quantitative and qualitative composition of dinocysts from the Santa Marta Formation and paleoecological interpretation of the assemblages; 2) timing of the bloom of dinocysts; 3) the relationship between sea-level fluctuations and the composition of dinocyst assemblages; and 4) reconstruction of lower-middle Santonian dinocyst assemblages based on their stratigraphic distribution to decipher the controlling mechanisms.

\section{LARSEN BASIN}

LOCATION

The Larsen Basin is a major sedimentary basin on the eastern side of the Antarctic Peninsula (Fig. 1). This basin was developed in a back-arc setting with respect to a volcanic arc formed by the subduction of a proto-Pacific oceanic crust beneath Gondwana (Macdonald et al. 1988, Hathway 2000). The opening of the Weddell Sea may have been responsible for the oblique extension along the eastern margin of the Antarctic Peninsula volcanic arc and may have influenced the evolution of backarc sedimentary basins from the Late Jurassic to the Late Cretaceous (Storey and Nell 1988, Storey et al. 1996). The Larsen Basin subsidence began in the Jurassic as a result of continental rifting during the early stages of the breakup of Gondwana, and its sediment fill was wholly derived from the volcanic arc. The northern part of the Larsen Basin was defined as the James Ross Sub-basin by Del Valle and Fourcade (1992). The volcano-sedimentary sequences are best exposed on and around James Ross Island (Fig. 1), where a nearly complete Aptian-Eocene succession crops out.

\section{SANTA MARTA FORMATION}

The Santa Marta Formation was originally subdivided informally into Alpha, Beta, and Gamma members (Olivero et al. 1986); however, due to great lithostratigraphic similarity, between the Alpha and Beta members, Crame et al. (1991) merged these members into one, and denoted them as the Lachman Crags Member. The Gamma Member was renamed as the Herbert Sound Member.
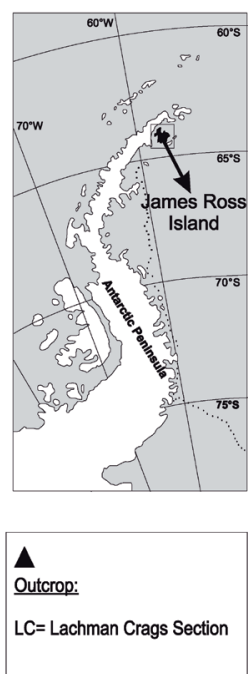
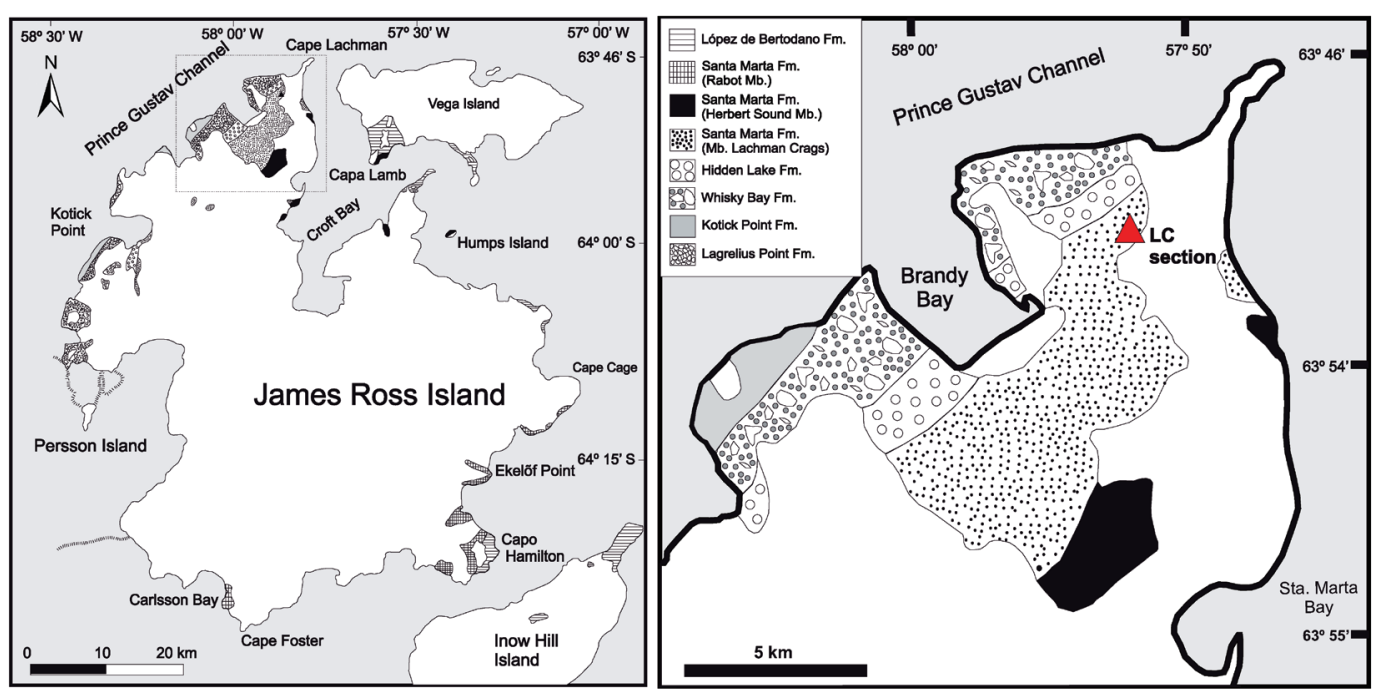

Figure 1 - Location map showing the studied outcrop of the Lachman Crags Member. 
The Santa Marta Formation comprises interbedded sandstones, siltstones, mudstones, and tuffs with accretionary lapilli and rare conglomerated sand coquinas (Crame et al. 2006). These deposits accumulated in a marine inner to outer shelf below a storm wave base with significant volcaniclastic supply (Pirrie et al. 1991).

Crame et al. (1991) formally divided the Santa Marta Formation into three members: the lower Lachman Crags Member and the upper Herbert Sound Member, which crop out in northwest James Ross Island, and the Rabot Member in southeast James Ross Island. The Lachman Crags Member, which is the focus of this study, is a sequence of sandstones and bioturbated silty sandstones and mudstones with a setting ranging from mid-shelf to outer shelf (Pirrie 1989, Crame et al. 1991). This member has been dated using molluscan fauna and dinoflagellate cysts, which indicate an early Santonian-early Campanian age (Crame et al. 1991, Keating 1992). However, more recent studies suggest that the Coniacian-Santonian boundary is within the lower $150 \mathrm{~m}$ of the Lachman Crags Member (McArthur et al. 2000); hence, a late Coniacian-early Campanian age is likely.

According to Crame et al. (1991), the Lachman Crags Member is equivalent to the Alpha and Beta members reported by Olivero et al. (1986). In a recent study, Olivero (2011) suggested a regressive sequence for the Alpha and Beta members of the Santa Marta Formation.

\section{MATERIALS AND METHODS}

The 30 samples analyzed in this study were collected from an outcrop belonging to the Lachman Crags Member (Santonian-Campanian), Santa Marta Formation, during fieldwork $(2006 / 2007)$ by a team from the National Museum of the Federal University of Rio de Janeiro (UFRJ). The Lachman Crags section (LC) analyzed in this study is $\sim 50$ $\mathrm{m}$ thick (Fig. 2). It is essentially a monotonous succession of intensely bioturbated sandstones, siltstones and mudstones. Therefore, the section is represented by one facies association. A significant proportion of the pelitic layers may, in fact, be altered volcanic tuffs, as suggested by the high amount of carbonized wood fragments. At the 10.5$\mathrm{m}$ level, the section is composed of fine sandstone, large fossilized wood fragments of up to $4 \mathrm{~m}$ in length and carbonate concretions with diameters ranging from 0.5 to $2.4 \mathrm{~m}$ conformable with the bedding plane (Fig. 2). Pirrie (1987) positioned this concretion horizon approximately $90 \mathrm{~m}$ above the base of the Marambio Group. These concretions also contain ammonites, bivalves, well-preserved plants and biogenic debris. The LC section is located in the area where Olivero (2011) defined the Alpha and Beta members, and seems to be related to the basal part of the Alpha Member given the similarity of the facies and the occurrence of carbonized plants and large tree trunk fragments.

The samples were prepared at the Laboratório de Paleoecologia Vegetal, Museu Nacional, Universidade Federal do Rio de Janeiro in Rio de Janeiro using the standard Petrobras method of palynological preparation compiled by Uesugui (1979) based on the methods developed by Erdtman (1943, 1969) and Faegri and Iversen (1966), among others. In this method, the mineral constituents are destroyed by hydrochloric and hydrofluoric acids before heavy-liquid separation. The remaining organic matter was sieved through a $10-\mu \mathrm{m}$ mesh prior to mounting on slides. The samples were analyzed under transmitted light and blue fluorescence microscopes. The analysis was based on the first 200 palynomorphs counted for each slide.

The paleoenvironmental interpretation was supported using the association of dinoflagellate cysts (dinocysts) revealed by cluster analysis. Cluster analysis based on abundance and composition was employed to establish groupings and to recognize the relationship between taxa (palynological analysis). The results are displayed in dendrograms. 

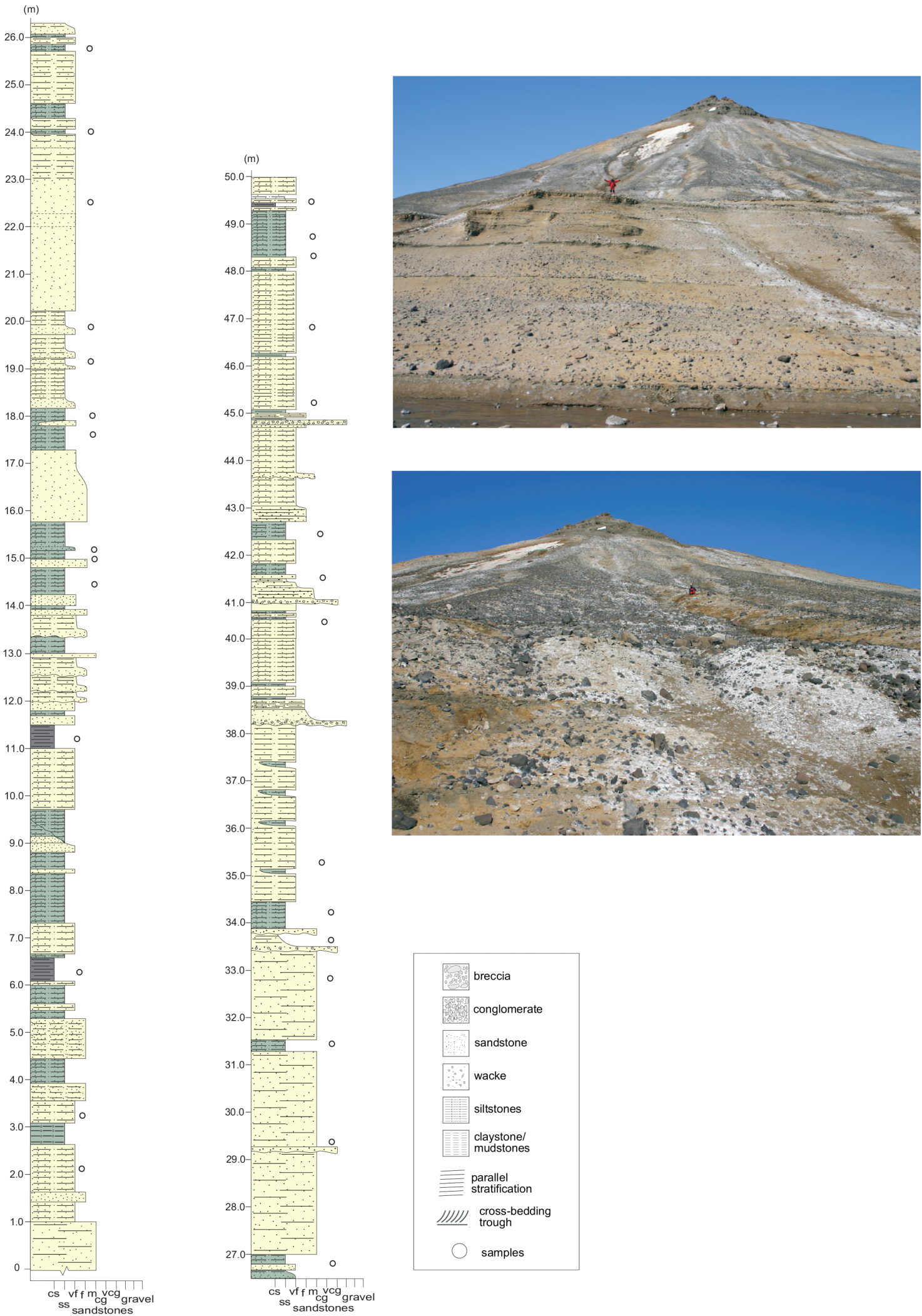

Figure 2 - Lithological profile of Lachman Crags section (LC). Photos showing the LC section. 
Diversity (Shannon-Weaver), equitability and dominance indices were calculated for all of the samples using the PAST software. The ShannonWeaver diversity $\mathrm{H}(\mathrm{S})$, which takes into account the abundance of each species, was used to characterize the diversity of the assemblages. The equitability index or evenness was calculated to describe the equity within assemblages. The evenness equals 1 if the abundances of all species are equal and approaches zero if one species dominates the assemblage. Dominance usually produces the opposite pattern in the diversity index. High values of dominance are usually associated with a domain of a species or even a group that has taken advantage of unfavorable conditions in the environment.

The peridinoid to gonyaulacoid $(\mathrm{P} / \mathrm{G})$ ratio or heterotrophic/autotrophic ratio introduced by Harland (1973) was also employed to reconstruct the changes in primary productivity in the geologic past (e.g., Eshet et al. 1994, Versteegh 1994, Brinkhuis et al. 1998). A peridinioid-dominated assemblage reflects low salinity and nutrient-rich conditions (Jaminski 1995) related to near-shore environments. In contrast, low values of the ratio, i.e., gonyaulacoid-dominated assemblages, indicate open marine environments. The ratio is used herein in the manner described by Versteegh (1994), whereby $\mathrm{P} / \mathrm{G}=\mathrm{nP} /(\mathrm{nP}+\mathrm{nG})$, where $\mathrm{n}=$ the number of specimens counted, $\mathrm{P}=$ protoperidinioid dinoflagellate cysts (P-cysts) and $\mathrm{G}=$ gonyaulacoid dinoflagellate cysts (G-cysts).

The continental/marine $(\mathrm{C} / \mathrm{M})$ ratio used herein was also described by Versteegh (1994). The ratio of continental to marine palynomorphs $(\mathrm{C} / \mathrm{M})$ is calculated as $\mathrm{C} / \mathrm{M}=\mathrm{nC} /(\mathrm{nC}+\mathrm{nM})$, where $\mathrm{n}=$ the number of specimens counted, $\mathrm{C}=$ spores + pollen grains and $\mathrm{M}=$ dinocysts + acritarchs. The ratio was used in this study to reconstruct the changes in terrestrial inputs to the basin.

\section{RESULTS}

Twenty-two species of dinocysts were recognized in the samples (Appendix). The dinocyst assem- blage was dominated by peridinioid dinocysts and demonstrated close affinities with Austral forms (Fig. 3). Isabelidinium was the most abundant dinocyst genus in the studied section, and the abundance curve showed low oscillation (Fig. 6). Dettman and Thomsom (1987) include Isabelidinium as one of four suggested dinoflagellate flora for the Antarctic Cretaceous and date the Isabelidinium flora as Santonian.

The diversity index $\mathrm{H}(\mathrm{S})$ varied from 0.38 to 2.59 taxa, with an average of 2.02, whereas the equitability $(\mathrm{J})$ varied from 0.35 to 0.93 , with an average of 0.82 . These indices demonstrate a rich dinocyst assemblage, which is not uncommon for Santonian deposits at James Ross Island. The dominance index varied from 0.10 to 0.82 (average 0.20 ), reinforcing the presence of moderate to high diversity. The high values for dominance coincide with Odontochitina peaks.

\section{AGE ASSESSMENT}

The dinocyst assemblages are typically for the Austral region. Helby et al. (1987) proposed a dinoflagellate biozonation for the Late Cretaceous of Australia and defined superzones and zones (Fig. 4). The same zonal scheme was applied in this study. Two biozones were recognized in the LC section, namely Odontochitina porifera and Isabelidinium cretaceum biozones (Fig. 4), both of which are assigned an early to middle Santonian age in the studied section.

The base of the Odontochitina porifera Zone is defined by the oldest occurrence of Odontochitina porifera, and the top is defined by the oldest occurrence of Isabelidinium cretaceum. The suggested age for the Odontochitina porifera Zone is early Santonian. The base of the Isabelidinium cretaceum Zone is defined by the oldest occurrence of Isabelidinium cretaceum = Manumiella cretacea, and its top is defined by the oldest occurrence of Nelsoniella aceras; its age is suggested as middle to late Santonian. 

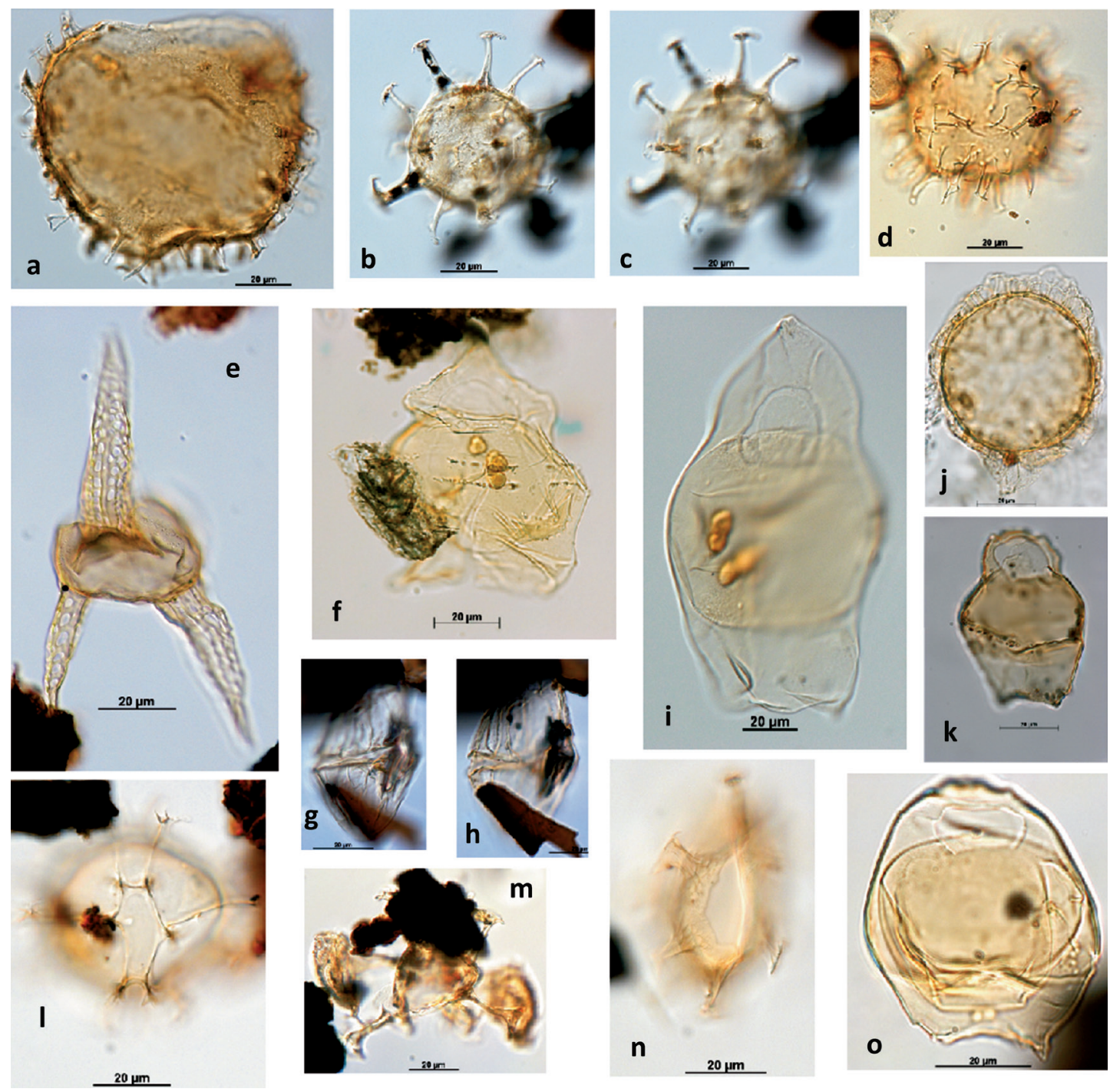

Figure 3 - The relevant dinocysts identified in the studied section: a) Cyclonephelium sp.; b-c) Oligosphaeridium sp.; d) Exchosphaeridium sp.; e) Odondochitina porifera; f) Chatangiella victoriensis; g-h) Dinogymnium nelsonense; i) Isabelidinium sp.; j) Chlamydophorella sp.; k) Amphidiadema spp.; l) Spiniferites sp.; m) Oligosphaeridium pulcherrimum; n) Heterosphaeridium sp.; o) Manumiella cretaceae.

The late Santonian age is not confirmed herein because Nelsoniella aceras was not recorded in the studied section.

\section{PALEOENVIRONMENTAL INTERPRETATION}

Cluster analysis was used based on the percentage of dinocystgenera and revealedfivedinocystassemblages (Fig. 5) designated by their most dominant taxa. The assemblages are Manumiella, Heterosphaeridium, Chlamydophorella, Isabelidinium and Odontochitina.
The Manumiella assemblage (average of $16.8 \%$ of the dinocyst assemblages) is composed only of Manumiella and Dinogymnium genera, the former which makes up an average of $16.7 \%$ of all of the dinocysts. The Heterosphaeridium assemblage is composed of Heterosphaeridium, Oligosphaeridium, Hystrichodinium and Cyclonephelium (average of $10.4 \%$ of all dinocyst assemblages). The Chlamydophorella assemblage has the lowest abundance (5.4\% of dinocyst assemblages), 
(a)

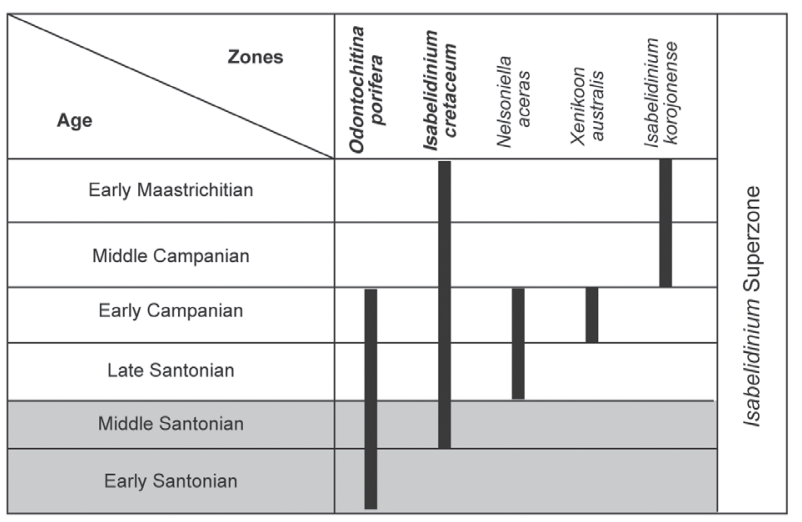

(b)

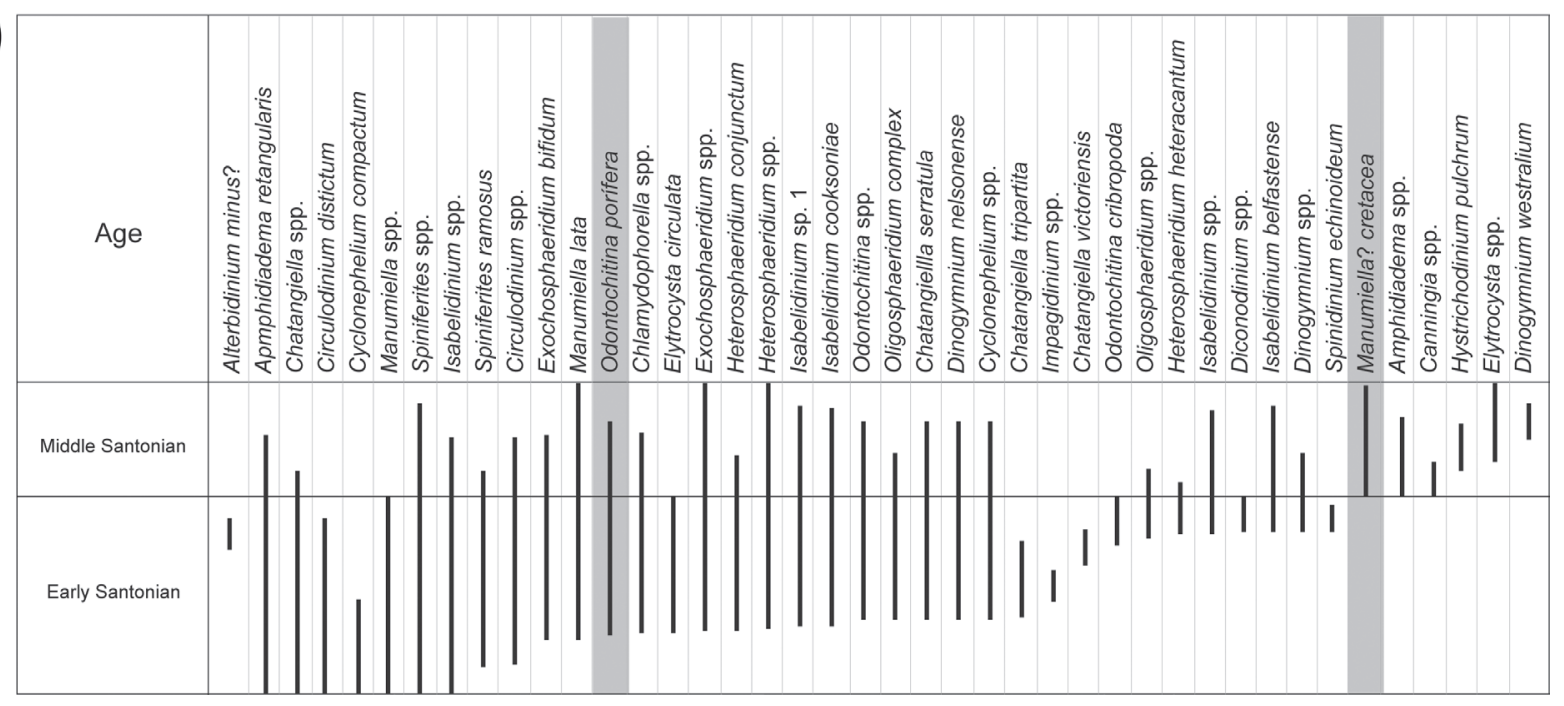

Figure 4 - a) Summarized zonation from Isabelidinium Superzone for Australian Mesozoic palynology from Helby et al. 1987. b) The stratigraphic distribution of dinoflagellates recorded in the studied succession. In gray the guide-species.

it is composed only of Chlamydophorella and Elytrocysta genera.

The Isabelidinium assemblage is composed only of Isabelidinium and Chatangiella genera; it is the second most abundant assemblage with an average of $30.7 \%$ of the total dinocysts. The most abundant assemblage is Odontochitina (36.4\%), it is composed ofOdontochitina, Exochosphaeridium, Circulodinium, Spiniferites and Amphidiadema. Despite being more abundant when compared to Isabelidinium assemblage, the Odontochitina assemblage has a higher standard deviation (18.7 vs. 21.7), which indicates a less consistent stratigraphic distribution along the section.

\section{Paleoenvironments and paleoecology in the} lower Santonian

In the lower Santonian, three intervals are characterized on the basis of the alternation of the two assemblages (Fig. 6). The first and third intervals, i.e., at the base and the top of the studied section, are dominated by the Isabelidinium assemblage. Isabelidinium have been used as indicators of inner neritic conditions (e.g., Dettman and Thomson 1987, Keating 1992, Thorn et al. 2009, Arai and Viviers 2013) and suggest that terrigenous inputs prevailed during this period. This is also implied by the high $\mathrm{C} / \mathrm{M}$ ratio values (Fig. 6). 


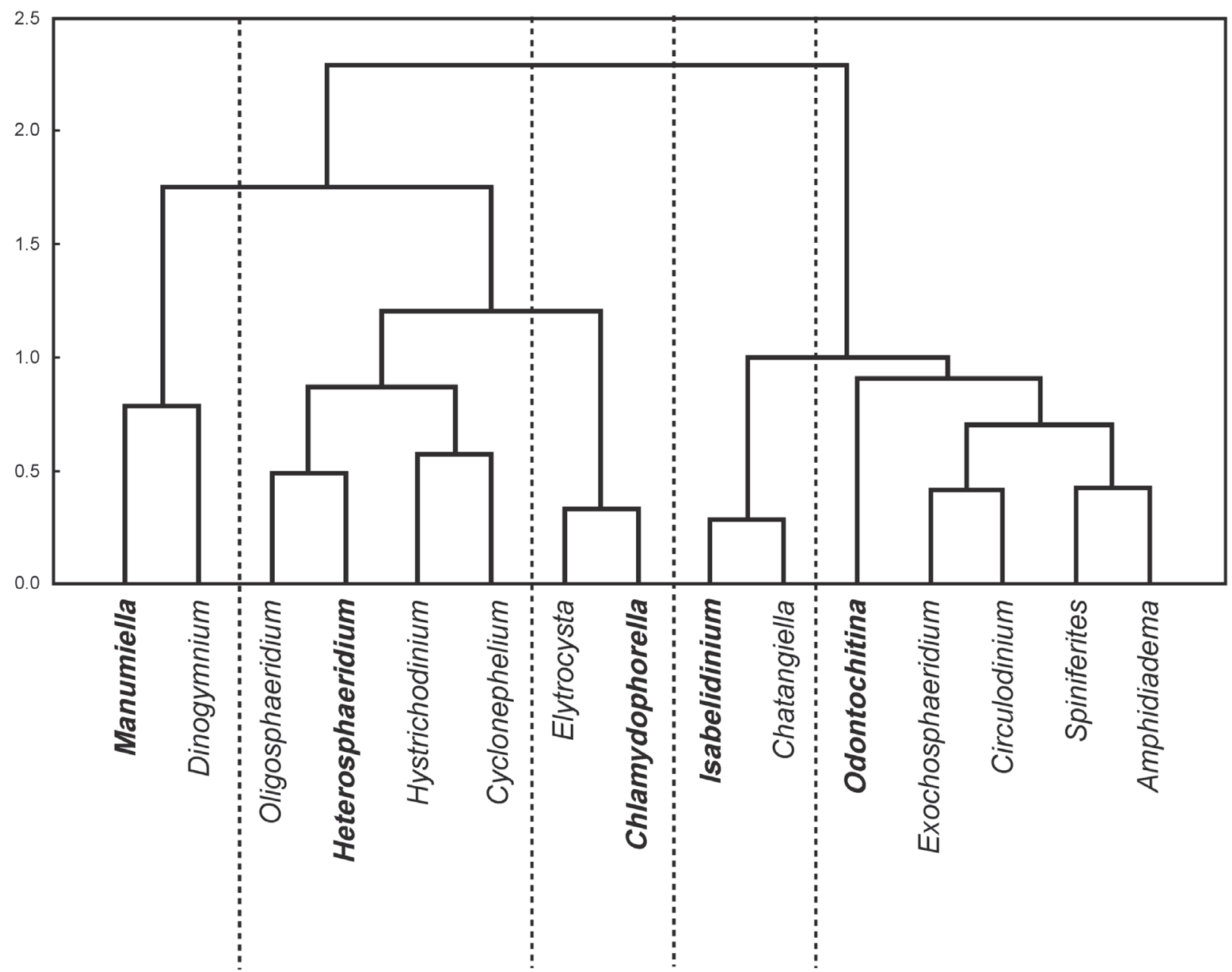

Figure 5 - Dendrogram (r-mode) of 15 dinocysts genera from the studied section showing the five assemblages. Names in bold is the name of assemblage.

An Isabelidinium bloom was recorded by Arai and Viviers (2013) for the Santos and Campos basins in Brazilian margins. These researchers suggest high runoff as the cause of the Isabelidinium bloom. In the studied section, the diversity indices reach an average of 2.0 in only one sample $(\mathrm{D}=2.6$ at $14.4 \mathrm{~m}$ ) (Fig. 6), corresponding to an increase in the percentage of the Heterosphaeridium assemblage and a decrease in percentage of the Isabelidinium assemblage. The equitability, however, remains stable and above average.

The high abundance of Isabelidinium species in the lower Santonian indicates, in general, an inner neritic depositional environment with considerable terrigenous influence (Fig. 7a-b). This paleoenvironmental interpretation is supported by the ternary diagram (cf. Tyson 1993, 1995) (Fig. 7b). The ternary diagram, in which interval points are dominated by Isabelidinium, concentrates on the near-shore field (Fig. 7b).

The cluster analysis of dinocyst assemblages after data normalization for sulfur \% (salinity), total organic carbon (TOC), $\mathrm{P} / \mathrm{G}$ (productivity) and $\mathrm{C} / \mathrm{M}$ (runoff) ratios (Fig. 7c) revealed that the Isabelidinium assemblage is related to TOC. This indicates that organic matter probably has a terrestrial origin. 


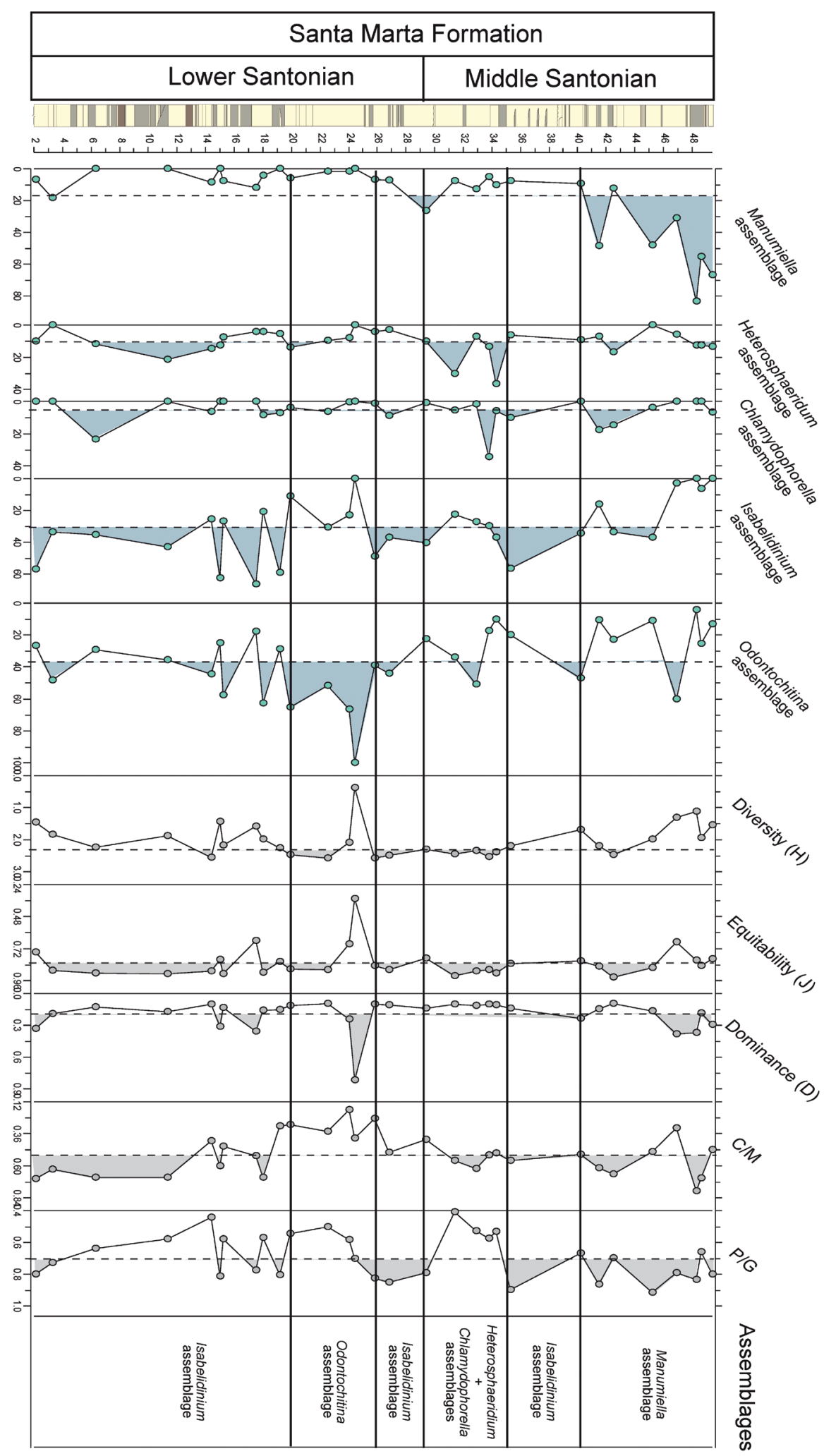

Figure 6 - Stratigraphic distribution of dinocyst assemblages and ecology indices and ratios. Abbreviations: $\mathrm{C} / \mathrm{M}=\mathrm{continental} /$ marine palynomorphs, $\mathrm{P} / \mathrm{G}=$ peridinioid to gonyaulacoid dinoflagellates cysts. Dashed line = average values. 
(a)
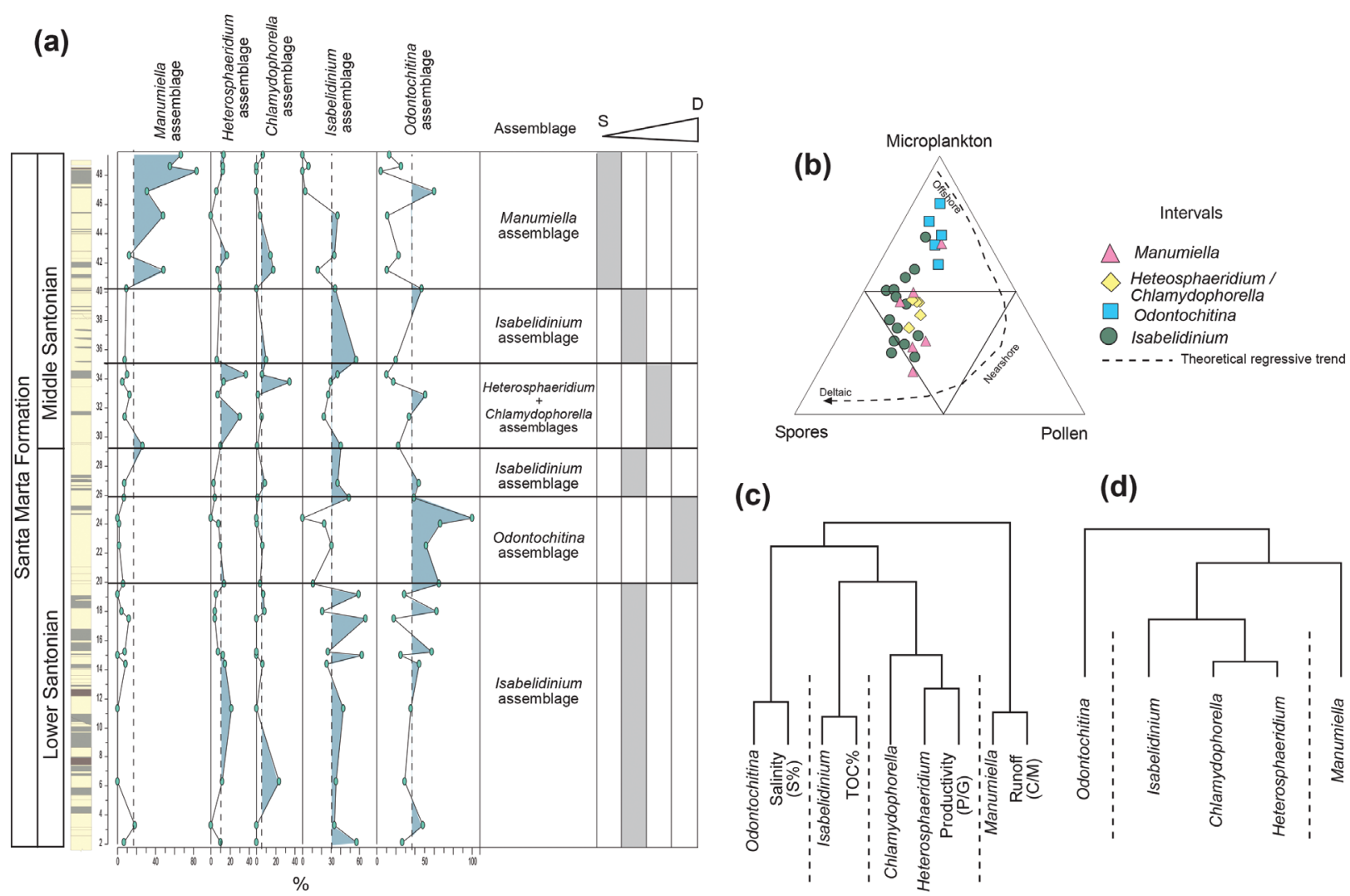

(c)

(d)
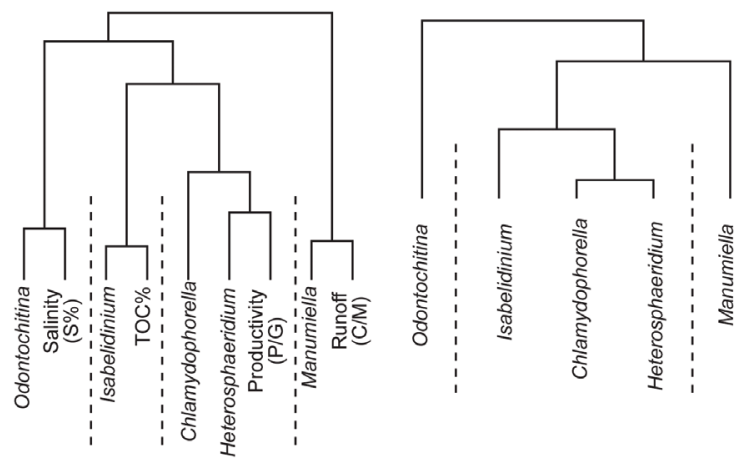

Figure 7 - a) Detailed stratigraphic column showing the succession of assemblage dominance. Paleobathymetry inferred from the assemblage data. $\mathrm{S}=$ shallow and $\mathrm{D}=$ deep. b) Ternary diagram showing the intervals and the dominant assemblages. c) Dendrogram (r-mode) of the assemblages and salinity from the Sulfur\%, carbon organic total (COT), productivity from the $\mathrm{P} / \mathrm{G}$ ratio and runoff from the $\mathrm{C} / \mathrm{M}$ ratio. d) Dendrogram of the dinocyst assemblages.

At a depth of $\sim 20 \mathrm{~m}$, a major environmental change is inferred on the basis of the high abundance of Odontochitina. In fact, the Odontochitina porifera conspicuously dominates the dinocyst assemblage. The high abundance of Odontochitina porifera coincides with the findings of Barreda et al. (1999), also on James Ross Island.

Lower values of diversity, equitability and $\mathrm{C} / \mathrm{M}$ ratio are indicated in this interval (Fig. 6). A prominent dominance peak reflects the Odontochitina assemblage domain. As for the Isabelidinium assemblage, the bloom of Odontochitina was also recorded by Arai and Viviers (2013) in the lower Santonian. This demonstrates that the blooms probably had a wider geographic scale. Moreover, Arai and Viviers (2013) related the decrease in continental nutrient supply to this bloom and suggested a more distal environment (middle neritic) compared to the Isabelidinium bloom. The sudden decrease observed in the $\mathrm{C} / \mathrm{M}$ curve suggests the same pattern for James Ross Island. However, Odontochitina has been used as an indicator of inner/restricted marine environments (e.g., Lister and Batten 1988, AbdelKireem et al. 1996, Courtinat, 1993). Skupien and Vašíček (2002) included Odontochitina in the saltmarshy paleoenvironment group (restricted shallow marine). Moreover, an existence of a monospecific assemblage is suggestive of restricted environmental conditions (Sangiorgi et al. 2008).

In this interval, the ternary diagram shows that the points are concentrated in the microplankton apices, reflecting a more marine condition (Fig. 7b). 
This condition is supported by the dendrograms shown in Figure 7c, where the Odontochitina assemblage is associated with moderate sulfur $\%$.

\section{Paleoenvironments and paleoecology in the middle Santonian}

Three intervals are also recognized in the middle Santonian (Fig. 6); these intervals contained four assemblages: Heterosphaeridium + Chlamydophorella, Isabelidinium and Manumiella.

The first interval is characterized by moderate values of dinocysts from the Heterosphaeridim and Chlamydophorella assemblages. This association is supported by the cluster analysis shown in Figure $7 \mathrm{~d}$. The Heterosphaeridium assemblage is composed of typical gonyaulacoid dinocysts. In general, the gonyaulacoids, especially chorates, indicate shelf environments with normal salinity conditions (e.g., Vozzhennikova 1965, Scull et al. 1966, Williams 1977, Tappan 1980, Sarjeant et al. 1987). Nevertheless, according to Bucefalo-Palliani and Riding (1998), the Chlamydophorella genus comprises chorate dinocysts that also indicate an inshore environment. This supports the slightly similar trend between the Heterosphaeridium assemblage and the Chlamydophorella and Isabelidinium assemblages (Fig. 7a, b). The Heterosphaeridim and Chlamydophorella assemblages are associated with the $\mathrm{P} / \mathrm{G}$ ratio (Fig. 7c); low values of the ratio reflect a high abundance of gonyaulacoids.

The ternary diagram (Fig. 7b) of the Heterosphaeridim and Chlamydophorella assemblage points are slightly more concentrated in the middle part of the ternary, which could suggest a slightly more distal environment in relation to the Isabelidinium assemblage. Barron et al. (2010) suggested that Chlamydophorella species are indicators of oligotrophic waters, which may reflect a paleoenvironment further away from the terrigenous source.

The second most abundant dinocyst in the Heterosphaeridium assemblage was Cyclonephelium
(4.2\% of all dinocysts), which has also been interpreted as an indicator of inner neritic conditions (Downie et al. 1971, Brinkhuis and Zachariasse 1988, Lister and Batten 1988).

The second interval is composed of only two samples, and the Isabelidinium assemblage is dominant (Fig. 6).

The third interval shows the conspicuous dominance of the Manumiella assemblage (Fig. 6). Manumiella is often associated with Isabelidinium (e.g., Thorn et al. 2009) because both are indicators of relatively near-shore, inner shelf marine environments. In fact, the ternary diagram in Figure $7 \mathrm{~b}$ shows that this interval is dominated by Manumiella species, and the points are concentrated at the spore apices. The dendrogram also supports the conclusion that the third interval represents the shallowest condition of the entire section. The Manumiella assemblage is associated with high runoff, as indicated by the C/M ratio (Fig. 7c).

Studies of Manumiella (e.g., Habib and Saeedi 2007, Thorn et al. 2009, Mohamed and Wagreich 2013) suggest a preference for more temperate conditions. Moreover, the high abundance of Manumiella coincides with sea-level changes associated with regressive periods (e.g., Askin 1988, Habib and Saeedi 2007, Thorn et al. 2009, Mohamed and Wagreich 2013). The high values of Manumiella, C/M ratios and $\mathrm{P} / \mathrm{G}$ ratios and the low values of diversity in the third interval (Fig. 6) reflect the shallow marine condition of the studied section.

\section{CONCLUSIONS}

The following conclusions were drawn from the results of the dinocyst assemblage and ecology indices of the LC section:

Cluster analysis of the lower-middle Santonian dinocyst records from the Lachman Crags Member yields five cyst assemblages: Isabelidinium, Odontochitina, Heterosphaeridium, Chlamydophorella, and Manumiella. 
In general, the lower-middle Santonian sequence typifies Austral assemblages. It is characterized by moderate to high species diversity and equitability, and the most abundant dinocysts are peridiniacean. This dominance is associated with the Odontochitina assemblage and may be related to the higher salinity interval.

The Manumiella assemblage is associated with shallow marine conditions.

The paleoenvironment varies from inner neritic with high runoff to middle neritic.

\section{ACKNOWLEDGMENTS}

This study was supported by the Coordenação de Aperfeiçoamento de Pessoal de Nível Superior (CAPES) scholarship to S.P. Castro, by the Conselho Nacional de Desenvolvimento Científico e Tecnológico (CNPq) grant no. 301573/2013-1 to M. Carvalho, the Fundação Carlos Chagas Filho de Amparo à Pesquisa do Estado do Rio de Janeiro (FAPERJ) grant no. E-26/103.028/2008 to M. Carvalho. We thank Petrobras geologist Dr. Mitsuru Arai for his valuable suggestions about dinocyst ecology. We thank the anonymous reviewers for their valuable suggestions.

\section{RESUMO}

Para entender melhor os paleoambientes do Santoniano inferior-médio, dados de dinocistos foram obtidos da Formação Santa Marta, Bacia Larsen, ilha James Ross, Península Antártica. Este estudo fornece os primeiros dados quantitativos de dinocistos para a Formação de Santa Marta, que refletem de forma mais detalhada as mudanças paleoambientais registradas a partir das curvas de flutuações de diversidade e abundância. Para registrar as assembleias de dinocistos do Santoniano da Bacia do Larsen, foram analisadas 30 amostras de um afloramento do Membro Lachman Crags (Seção LC). Estas assembleias são dominadas por dinocistos peridinióides típicos da flora Isabelidinium. As idades Eosantoniano e Mesosantoniano foram determinadas após o reconhecimento das zonas Odontochitina porifera e Isabelidinium cretaceum. Análise de agrupamento com base em dados quantitativos produziu cinco assembleias de dinocistos: Manumiella, Heterosphaeridium, Chlamydophorella, Isabelidinium e Odontochitina. Duas florações santonianas de Isabelidinium e Odontochitina, reconhecidas em outras regiões, também foram registradas na seção estudada. A distribuição estratigráfica mostra uma alternância entre as assembleias, dividindo a seção em seis intervalos. A abundância elevada da Assembleia Manumiella no intervalo superior da seção representa o ambiente marinho mais raso, enquanto que a alta abundância da Assembleia Odontochitina na parte média da seção representa um ambiente marinho mais profundo.

Palavras-chave: Dinocistos santonianos, Antártica, Cretáceo, Formação Santa Marta, florações de dinocistos.

\section{REFERENCES}

ABDEL-KIREEM MR, SCHRANK E, SAMIR AM AND IBRAHIM MIA. 1996. Cretaceous paleoecology, paleogeography and paleoclimatology of the North Western Desert, Egypt. J Afr Earth Sci 22: 93-112.

ARAI M AND VIVIERS MC. 2013. Dinoflagellate cyst super dominance assemblages from the Upper Cretaceous of the Santos Basin, offshore SE Brazil, and their palaeoecological significance. Lewis JM, Marret F and Bradley L (Eds), 2013. Biological and Geological Perspectives of Dinoflagellates. The Micropalaeontological Society, Special Publications. Geol Soc London, p. 285-292.

ASKIN RA. 1988. The palynological record across the Cretaceous/Tertiary transition on Seymour Island, Antarctica. Geol Soc Am Mem 169: 155-162.

BARREdA V, PALAMARCZUK S AND MEdinA F. 1999. Palinología de la Formación Hidden Lake (ConiacianoSantoniano), Isla James Ross, Antártida. Rev Esp Micropaleontol 31: 53-72.

BARrón E, Ureta S, GoY A AND LASSAletta L. 2010. Palynology of the Toarcian-Aalenian global Boundary Stratotype Section and Point (GSSP) at Fuentelsaz (Lower-Middle Jurassic, Iberian Range, Spain). Rev Palaeobot Palyno 162: 11-28.

BRINKHUIS H, BUJAK JP, SMIT J, VERSTEEGH GJM AND VISSCHER H. 1998. Dinoflagellate-based sea surface temperature reconstructions across the CretaceousTertiary boundary. Palaeogeogr Palaeocl 141: 67-83.

BRINKHUIS H AND ZACHARIASSE WJ. 1988. Dinoflagellates cysts from the Cretaceous/Tertiary boundary sequence of El Kef, NW Tunisia. Mar Micropaleontol 13: 153-191.

Bucefalo-Palliani R And Riding JB. 1998. The Palynology of the Toarcian-Aalenian transition in the Wittnau borehole (Oberrhein, Southwest Germany). Neues Jahrb Geol P-A 210: 143-184. 
COURTINAT B. 1993. The significance of palynofacies fluctuations in the Greenhorn Formation (CenomanianTuronian) of the Western Interior Basin, USA. Mar Micropaleontol 21: 249-257.

Crame JA, PIRrIE D AND RIDING JB. 2006. Mid-Cretaceous stratigraphy of the James Ross Basin, Antarctica. In: Francis JE, Pirrie D and Crame JA (Eds), CretaceousTertiary High-Latitude Palaeoenvironments: James Ross Basin, Antarctica. Geol Soc London SP 258: 7-19.

Crame JA, PIRrie D, Riding JB AND Thomson MRA. 1991. Campanian-Maastrichtian (Cretaceous) stratigraphy of the James Ross Island area, Antarctica. J Geol Soc London 148: 1125-1140.

Del VAlle RA AND FourCAdE NH. 1992. Sedimentary basins on the eastflank of the Antarctic Peninsula: proposed nomenclature. Antarct Sci 4: 477-478.

DetTMAnN ME AND ThOMSON MRA. 1987. Cretaceous palynomorphs from the James Ross Island area, Antarctica - a pilot study. Brit Antarct Surv B 77: 13-59.

DownIE C, Hussain MAAND WILLIAMS GL. 1971. Dinoflagellate cyst and acritarch associations in the Paleogene of southeast England. Geoscience and Man 3: 29-35.

ERDTMAN G. 1943. An introduction to pollen analysis. New York, Ronald Press, 239 p.

ERDTMAN G. 1969. Handbook of palynology. Copenhagen, Munksgaard (Scandinavian University Books), 486 p.

Eshet Y, ALmogi-LABIN A AND BeIn A. 1994. Dinoflagellate cysts, paleoproductivity and up-welling systems: a Late Cretaceous example from Israel. Mar Micropaleontol 23: 231-240.

FAEGri K AND IVERSEN J. 1966. Textbook of Pollen Analysis. Munksgaard, København, 237 p.

FEnsome RA AND WiLLIAMS GL. 2004. The Lentin; Williams Index of fossil dinoflagellates - 2004 edition. AASP Contr Ser 42: 1-909.

Francis JE, Crame JA AND Pirrie D. 2006. CretaceousTertiary high-latitude palaeoenvironments, James Ross Basin, Antarctica: introduction. In: Frances JE, Pirrie D and Crame JA (Eds), Cretaceous-Tertiary High-Latitude Palaeoenvironments, James Ross Basin, Antarctica. Geol Soc London SP 258: 1-5.

HABIB D AND SAEEDI F. 2007. The Manumiella seelandica global spike: cooling during regression at the close of the Maastrichtian. Palaeogeogr Palaeocl 255: 87-97.

HARLAND R. 1973. Dinoflagellate cysts and acritarchs from the Bear-paw Formation (upper Campanian) of southern Alberta, Canada. Palaeontology 16: 665-706.

HATHWAY B. 2000. Continental rift to back-arc basin: JurassicCretaceous stratigraphical and structural evolution of the Larsen Basin, Antarctic Peninsula. J Geol Soc London 157: 417-432.

Helby R, Morgan R And Partridge AD. 1987. A palynological zonation of the Australian Mesozoic. Mem Assoc Australas Palaeontol 4: 1-94.

JAMINSKI J. 1995. The mid-Cretaceous palaeoenvironmental conditions in the Polish Carpathians - a palynological approach. Rev Palaeobot Palyno 87: 43-50.
KeAting JM. 1992. Palynology of the Lachman Crags Member, Santa Marta Formation (Upper Cretaceous) of north-west James Ross Island. Antarct Sci 4: 293-304.

LiSTER JK AND BATTEN DJ. 1988. Stratigraphic and palaeoenvironmental distribution of Early Cretaceous dinoflagellate cysts in the Hurlands Farm borehole, West Sussex, England. Palaeontographica Abt B 210: 9-89.

MACDONALD DIM, BARKER PF, GARRETT SW, INESON JR, Pirrie D, Storey BC, Whitham AG, Kinghorn RRF AND MARSHALL JEA. 1988. A preliminary assessment of the hydrocarbon potential of the Larsen Basin, Antarctica. Mar Petrol Geol 5: 34-53.

MCARTHUR JM, BRAME JA AND THIRLWALl MF. 2000. Definition of the Late Cretaceous stage boundaries in Antarctica using strontium isotope stratigraphy. J Geol 108: 623-640.

MOHAMED O AND WAGREICH M. 2013. Organic-walled dinoflagellates cyst biostratigraphy of the Well Höflein 6 in the Cretaceous-Paleogene Rhenodanubian Flysch Zone (Vienna Basin, Austria). Geol Carpath 64: 209-230.

OLIVERO EB. 2011. Sedimentary cycles, ammonite diversity and palaeoenvironmental changes in the Upper Cretaceous Marambio Group, Antarctica. Cretaceous Res 34: 348366.

OLIVERO EB, SCASSO RA AND RINALDI CA. 1986. Revision of the Marambio Group, James Ross Island, Antarctica. Contrib Inst Antárt Argent 331: 1-28.

PIRRIE D. 1987. Orientated calcareous concretions from James Ross Island, Antarctica. Brit Antarct Surv B 75: 41-50.

PIRRIE D. 1989. Shallow-marine sedimentation within an active margin basin, James Ross Island, Antarctica. Sediment Geol 63: 61-82.

PIRrie D, Whitham AG AND InESON JR. 1991. The role of tectonics and eustasy in the evolution of a marginal basin: Cretaceous-Tertiary Larsen Basin, Antarctica. In: Macdonald DIM (Ed), Sedimentation, Tectonics and Eustasy. International Association of Sedimentologists, Special Publications 12: 293-305.

SANGiorgi F, BRUMSACK HJ, Willard DA, SCHOUTEN $\mathrm{S}$, Stickley CE, O'Regan M, Reichart GJ, SinNINGHEDAMSTE JS AND BRINKHUIS H. 2008. A 26 million years gap in the central Arctic record at the Greenhouse-Icehouse transition: Looking for clues. Paleoceanography 23: PA1S04-PA1S04/13.

SARJEANT WAS, LACALli T AND GAINES G. 1987. The cysts and skeletal elements of dinoflagellates: Speculations on the ecological causes for their morphology and development: Micropaleontology 33: 1-36.

Scull J, Felix CJ, Mccalebs B and Shaw WG. 1966. The inter-discipline approach to paleoenvironmenal interpretations. Trans GCAGS 16: 81-117.

SKUPIEN P AND VAŠÍČEK Z. 2002. Barremian and Aptian integrated biostratigraphy (ammonites and non-calcareous dinocysts), paleoenvironment and paleoclimate in the deposits of the Silesian nappe in the Czech Republic's territory (Outer Western Carpathians). Geol Carpathica 53: $1-11$. 
STOREY BC AND NELL PAR. 1988. Role of strike slip faulting in the tectonic evolution of Antarctic Peninsula. J Geol Soc London 145: 333-337.

Storey BC, Vaughan AEM AND Millar IL. 1996. Geodynamic evolution of the Antarctic Peninsula during Mesozoic times and its bearing on Weddell Sea history. In: Storey BC, King EC and Livernore RA (Eds), Weddell Sea Tectonics and Gondwana Break-up. Geol Soc London SP 108: 87-103.

TAPPAN H. 1980. The Paleobiology of plant protists: Freeman, San Francisco, 678 p.

Thorn VC, RIDING JB AND FrancIS JE. 2009. The Late Cretaceous dinoflagellate cyst Manumiella Biostratigraphy, systematics, and palaeoecological signals in Antarctica. Rev Palaeobot Palyno 156: 436-448.

TYSON RV. 1993. Palynofacies analysis. In: Jenkins DJ (Ed), Applied Micropalaeontology, Kluwer Academic Publishers, Dordrecht, p. 153-191.
TYSON RV. 1995. Sedimentary organic matter: Organic facies and palynofacies. Dordrecht, Holland, Kluwer Academic, $615 \mathrm{p}$.

Uesugui N. 1979. Palinologia: técnicas de tratamento de amostras. Boletim Técnico da Petrobras 22: 229-240.

VERSTEEGH GJM. 1994. Recognition of cyclic and non-cyclic environmental changes in the Mediterranean Pliocene. Mar Micropaleontol 23: 141-171.

VozZHENNIKOVA TF. 1965. Introduction to the Study of Fossil Peridinian Algae (Translated by Syers K, edited by Sarjeant WAS): Boston Spa, Yorkshire, England, National Lending Library for Science and Technology of page, $123 \mathrm{p}$.

WILLIAMS GL. 1977. Dinocysts. Their classification, biostratigraphy and palaeoecology. In Ramsey ATS (Ed), Oceanic Micropalaeontology. Academic Press, London 2: 1231-1325. 


\section{APPENDIX}

\section{(Identified dinocyst taxa)}

Amphidiadema spp. indet.

Canningia spp. indet.

Chatangiella spp. indet.

Chatangiella tripartita (Cookson and Eisenack, 1960.) Lentin and Williams, 1976. Chatangiella multispinosa (Cookson and Eisenack, 1970) Lentin and Williams, 1976.

Chatangiella victoriensis - (Cookson and Manum, 1964) Lentin and Williams, 1976. Emendation: Lebedeva in Ilyina et al., 1994, as Chatangiella victoriensis.

Chlamydophorella spp. indet.

Circulodinium distictum - (Deflandre and Cookson, 1955.) Jansonius, 1986.

Circulodinium spp. indet.

Cyclonephelium compactum - Deflandre and Cookson, 1955.

Cyclonephelium spp. indet.

Diconodinium spp. indet.

Dinogymnium nelsonense - (Cookson, 1956.) Evitt et al., 1967.

Dinogymnium spp. indet.

Dinogymnium westralium - (Cookson and Eisenack, 1958.) Evitt et al., 1967. Emendation: May, 1977, as Dinogymnium westralium.

Elytrocysta circulate - (Clarke and Verdier, 1967.) Stover and Helby, 1987.

Elytrocysta spp. indet.

Exochosphaeridium bifidum - (Clarke and Verdier, 1967.) Clarke et al.,1968. Emendation: Davey, 1969 as Exochosphaeridium bifidum.

Exochosphaeridium phragmites - Davey et al., 1966. Exochosphaeridium spp. indet.
Heterosphaeridium conjunctum - Cookson and Eisenack, 1968.

Heterosphaeridium heteracantum - (Deflandre and Cookson, 1955.) Eisenack and Kjellström, 1972.

Heterosphaeridium spp. indet.

Hystrichodinium pulchrum - Deflandre, 1935.

Impagidinium spp. indet.

Isabelidinium belfastense - (Cookson and Eisenack, 1961) Lentin and Williams, 1977.

Isabelidinium sp1.

Isabelidinium $\mathrm{sp} 2$.

Isabelidinium spp. indet.

Manumiella lata - (Cookson and Eisenack, 1968)

Bujak and Davies, 1983.

Manumiella spp. indet.

Manumiella cretacea - (Cookson, 1956). Bujak and

Davies, 1983.

Odontochitina cribropoda - Deflandre and

Cookson, 1955

Odontochitina porifera - Cookson, 1956

Odontochitina spp. indet.

Oligosphaeridium complex - (White, 1842) Davey and Williams, 1966.

Oligosphaeridium pulcherrimum - (Deflandre and Cookson, 1955) Davey and Williams, 1966.

Oligosphaeridium spp. indet.

Spinidinium echinoideum - (Cookson and Eisenack, 1960) Lentin and Williams, 1976. Emendation: Sverdlove and Habib, 1974 as Deflandrea echinoidea

Spiniferites ramosus (Ehrenberg, 1838) Mantell, 1854.

Spiniferites spp. indet. 
